Brandeis $\mid$ urear

brandeis.edu/j-caste
CASTE: A Global Journal on Social Exclusion

Vol. 2 No. I pp. 47-66

April 2021

ISSN 2639-4928

DOI: 10.26812/caste.v2i1.247

\title{
Documenting a Caste: The Chakkiliyars in Colonial and Missionary Documents in India
}

\author{
S. Gunasekaran'
}

\begin{abstract}
This essay is an attempt to write the social history of the Chakkiliyar community of South India, often classified in the colonial records as a caste occupying the lowest position in the caste hierarchy. This paper argues that the colonial period was marked by lowering opportunities for economic and social mobility for the community. Traditionally involved in the manufacture of leather goods that were central to irrigation, the Chakkiliyars had relatively better opportunities and some even occupied the status of petty landowners. But the advent of pumpsets and the mechanization of leather processing during the colonial period severely affected their economic opportunities. Adding to this, the colonial and missionary records, inflated with the prejudices of their upper caste informers, repeatedly portrayed their low social existence. Therefore, despite certain genuine motives and formidable social reforms, the colonial and missionary documentation of the caste in fact further strengthened the existing social stereotypes and thus added yet another layer into its history of discrimination. Besides recovering the various ways in which Chakkiliyars were described in the documents of colonial officials and Christian missionaries, this paper also analyzes the recent attempts by the members of the community to produce a counter narrative to the stereotypical representations of their caste.
\end{abstract}

\section{Keywords}

Chakkiliyar, Arunthathiyar, leather workers, untouchable castes, socioeconomic mobility

\footnotetext{
'Centre for Historical Studies, Jawaharlal Nehru University, New Delhi, India E-mail:jsguna@gmail.com
}

(C) 202 I S. Gunasekaran. This is an open access article distributed under the terms of the Creative Commons Attribution License, which permits unrestricted use, distribution, and reproduction in any medium, provided the original author(s) and source are credited. 


\section{Introduction}

Caste identities in South India were much complex than the way they were portrayed in colonial census surveys. ${ }^{1}$ Despite various cultural and social restrictions, castes migrated for better economic opportunities, adopted new caste titles, reframed their origin myths, and thus, aspired for a respectable social identity. Such flexibility and mobility, however, were more prevalent among the castes in the middle order of the social hierarchy than others. ${ }^{2}$ Inversely, certain castes - especially those from the lower end of the social spectrum - fell into a 'social trap' to the extent that their social mobility became virtually impossible. Every successive stage in history left them with irrevocable cultural and economic curbs. The layered cultural prejudices and stereotypes correspondingly diminished their economic opportunities and furthered the struggles for survival. It is, therefore, not necessary that the social history of a caste will always show how the community gradually empowered itself economically to achieve a higher social status, as has been the case with most histories of lower castes, but it could also be the other way round; showing how it slowly lost its social significance and was reduced to a slave caste.

The social history of the Chakkiliyar caste that the paper attempts to trace falls into the latter category. This paper is a small part of a larger ethnohistory project that strives for a comprehensive history of the Chakkiliyars and conceptualizes its historical experience - of being 'untouchable among the untouchables' - in a broader context of the history of lower caste and mobilizations in South Asia. The discussion here focuses on the representation of the caste in the records of colonial administrators and Christian missionaries and discusses how, despite certain genuine motives and formidable social reforms, the colonial and missionary documentation of the caste in fact further strengthened the existing social stereotypes and thus added yet another layer to its history of discrimination.

\section{Chakkiliyar Historiography}

Writings on the history of the Chakkiliyars are very few and they mostly deal with the contemporary history of the caste. Michael Moffatt (1979) undertook a villagelevel study. His work, among other aspects, also explored the replication of caste hierarchies among 'untouchables' within the village, the Endavur of Chenglepet district. He presented a descriptive analysis of the occupation and internal ranking of the Chakkiliyars within what he called the Harijan (untouchable) communities. 'The Chakkiliyars were at one time excluded from habitation in the colony, just as the higher untouchables are excluded from habitation in the uur (village).' Therefore, the Chakkiliyars and a few other castes, such as the Kuruvikaran and the Pudirai Vannan,

${ }^{1}$ However, such a proposition is debated by the historians, see Inden, R. (1990). Imagining India, Oxford: Blackwell.; Dirks, N. (2001). Castes of mind: colonialism and making of modern India. Princeton: Princeton University Press.; Guha, Sumit. (2003). The politics of identity enumeration in India 1600-1990. Comparative Studies in Society and History, 45, pp. 148-167. ${ }^{2}$ For example, Vijaya Ramaswamy. (2004). Vishwakarma craftsmen in early medieval peninsular India. Journal of the Economic and Social History of the Orient, 47(4), pp. 548-582.; Blackburn, Stuart H. (2007). The Kallars: a Tamil 'criminal tribe' reconsidered. South Asia: Journal of South Asian Studies, 1(1), pp. 38-51.; Hardgrave Jr., Robert L. (1969). The Nadars of Tamil Nadu: the political culture of a community in change. Bombay: Oxford University Press. 
as Moffatt's study has shown, were untouchables within the untouchable castes. While most contemporary studies on South Indian lower castes focussed on the Paraiyars, few like that of Moffatt, were directed towards the lowest rungs of untouchable communities. Gunnel Cederlöf's Bonds Lost (1997) is perhaps the first systematic historical study on the Chakkiliyars, called the Madhariyar, in western Tamil Nadu. With the help of colonial and missionary archives, Cederlöf studied the economic role and social mobilization of the Chakkiliyars in the first half of the twentieth century in the Coimbatore region. The Pannaial system (master and slave), the social relationship that existed between the landholding, the Gounder, and the landless labourers, the Chakkiliyar, was disturbed through waves of industrialization, introduction of water pumpsets, and successive famines and droughts in the region. In that context, conversion to Christianity extended a ray of hope for social mobilization. Works of a few French scholars have also contributed to the Chakkiliyar historiography. Of these, Alexandra de Heering's Speak, Memory: Oral Histories of Kodaikanal Dalits is a recent one (2018). She reconstructs the history of the community through memories collected from the people living in two villages in the Kodaikanal region.

Among the studies published in Tamil, Margu's (2001) anthropological, ethnological account provided a participant observation about the contemporary sociocultural life, rituals, and cult practices of the Chakkiliyars. There were some young academics and activists, such as R. Athiyaman, Ezhil Elangovan, M. Mathivanan and Jayaveeradevan, whose various works ${ }^{3}$ challenged the stereotypical socio-cultural constructions about the caste and generated historical awareness so as to liberate them from the feeling of low self-esteem. They narrated what they called 'the hidden history'. Most of their articles appeared in a Tamil magazine, Vellai Kuthirai (White Horse), which was published by them. The title, White Horse, symbolized the glorious warrior past of the community. They put forth various isolated historical incidents where the leaders of the community were either rulers or closely associated with the ruling class, such as the Nayakas and the Palayakkarars. In these accounts several members from the community participated in the freedom struggle, protected the capital city from being attacked by bandits, transgressed caste restrictions, and rebelled against unlawful taxation. Such accounts helped enormously in mobilizing the people politically, challenging the social suppression, and helping them in demanding special reservation in educational and employment opportunities.

The community is known for maintaining its rich tradition of oral narratives. Some of them, such as Maduraiveeran Kathai, Muthupattan Kathai and Ondiveeran Kathai are very popular and many historians and folklorists have analyzed the social and historical context of these narratives. In this context, the works of Vanavamalai (1971), Blackburn (1978) and Arunan (2010) need special mention. The story, Mathuraiveeran, was made into a film, which was analyzed by M. S. S. Pandian (2001) in the context

${ }^{3}$ For example, Ezhil. Elangovan. (2004). Maaveerarn ondiveeran pagadai. Coimbatore: Adhi Tamishar Peravai.; Ezhil. Elangovan. (2003). Madhurai Veeran KolaiyumThirumalai Nayakkar Mahalum. Tanjore: Pournami Samuka Araichi Maiyam.; R. Adhiyman. (2007). Aadhitamizharkalin Porkural, Coimbatore: Adhi Tamishar Peravai.; M. Mathivanan. (2008). Arunthathiyarakiya Nangal Coimbatore: Adhi Tamishar Peravai.; Adhiyamaan. (2011). 'Chakkiliyar Liberation is the pre-condition for the Liberation of the Downtrodden' in Susie Tharu and K. Satyanarayanan (ed.). No Alphabet in Sight, Delhi: Penguin Books.; Jayaveeradevan. (2018). Ceruppu. Chennai: Pavai Publication. 
of the subaltern history and politics in South India. Within a similar analytical lens, Sundar Kali (2010) studied hagiographies of Dalit bhakts (devotees), the Shaivites and Vaishnavites. The story of Chakkiliya Swamigal, a Vaishnavite, symbolized an attempt of a man from the Chakkiliyar community to transgress the norms laid out by the Brahmins during the early medieval period. Rituals and cult practices associated with temple festivals, such as masikalarai, and shoe offerings in Sorimuthu Ayyanar temple are also referred to in some studies (Arunan, 2010). They, together with numerous folk songs, offer an enormous scope to reconstruct the social history of the community (Srinivasan \& Ponraj, 2010). In short, there are two trends which emerge from the existing historiography: the first traces the slave past of the community - the pannaiyals (farm workers), leather workers, and municipal sweepers; and the second focuses on its glorious past - brave warriors, rulers, and rebels.

\section{Arunthathiyar: The Myths of Origin}

Today, people of the Chakkiliyar community prefer to be called Arunthathiyar. The myth supporting this new identity is of more recent origin. Asserting a new identity, in fact, is an attempt to depart from the 'accidental' slave past and various stereotypically constructed characteristics associated with the caste. While Chakkili signified people who eat the flesh of dead cows and engage in the so-called impure jobs, Arunthathiyar, derived from the name of the morning star, meant purity, pristine, and a revolutionary rising. In the early Hindu Puranic legends, Arunthathi was a Chakkili (chandala low caste) woman who was married to Vasishtha, ${ }^{4}$ the son of Urvashi. ${ }^{5}$ Stories of origin also attempted to connect the past of the community with the ancient Tamils. It becomes vital since some sections of the community speak both Telugu and Kannada, and therefore there was a threat of their being considered as migrants to Tamil region. According to a story, the term 'Arunthathiyar' comes from the name of Athiyar - a famous tribe that ruled the western part of Tamil Nadu during the classical period. Athiyaman Neduman Anji, a chief known for his bravery and philanthropy, came from this tribe (Marxiagandhi, 1998). The heroism and generosity of Athiyars is a notable theme in ancient Tamil Sangam literatures in which Tamil castes always trace their origin so as to assert their indigeneity. The modern Dharmapuri region is identified as a territory of the Athiyaman, where a large proportion of the Chakkiliyar population still lives.

To the dominant castes, to whom the Chakkiliyars rendered their services, the traditional identity of Chakkili is more preferable. It is used often in a demeaning way to mean unclean, degraded, and filthy. In Sri Lanka, where the Chakkiliyars migrated to work in the colonial tea plantations, the word Chakkili is a derogatory Sinhala term for Tamil minority and Muslims. ${ }^{6}$ Invocation of the word, Chakkiliyar, especially by the upper castes in rural places, indirectly indicates the power that they enjoyed being dominant till recently and also reminded the Chakkiliyars of their degraded

\footnotetext{
${ }^{4}$ According to the Hindu Mythology, Vasishtha is one of the seven great Vedic sages, supposed to be the human son of the Hindu god Brahma.

${ }^{5}$ According to the Hindu mythology, Urvashi is one of the apsaras (celestial beings with supernatural powers) residing in the domain of king of gods, Indra.

${ }^{6}$ See, Trawic, Margaret. (2017). Death, beauty, struggle: untouchable women create the world, Philadelphia: University of Pennsylvania Press. (p. 35).; Saravanan Nadarasa. (2019). 'Sathiya Vasaipadal: Arunthathiyar Samukathai Munvaithu', Kaakai Sirakinile, March.
} 
social position. While there was an attempt, among the first generation educated Chakkiliyars, to erase the past by calling themselves Arunthathiyar, there were also some who used the suffix of Chakkiliyar with their personal name as an act of assertion. Reconstruction of the Chakkiliyar history, which has just begun, was realized as a way to give the term Chakkili a new meaning.

Many futile etymological attempts were made to decode the meaning of the word Chakkili. It is often said that the word emerges from the Sanskrit and Kannada words for leather. The word, of medieval origin, retains to some extent of phonetic similarity with cemman (ancient Tamil leather workers) and chamar (leather worker in North India). Otherwise, the word provides no clue regarding the history of the community. B. S. Baliga (1957, p. 263) connects the word with the character of the people of the caste. He writes:

The term Chakkili means people afraid of beating. Some scholars are of the opinion that once, during the time of Nayak kings, they were sacrificed after building forts and palaces. Because of such events, and as they were killed, they became afraid of everything and hence were called as Chakkili.

Even after centuries of suppression and humiliation, there were hardly any significant movements that emerged from this caste. People of this community, it is often said, are obedient, submissive, and non-aggressive. Baliga gives a list of castes that claim the Arunthathiyar identity in modern times. It includes: Chakkiliyar, Pakadai, Mathariyar, Madika, Thottiyar, Thomman, Cemman, Thotti, and Adi Andhra.

In recent census reports, all these sub-castes are generally classified into two categories - a. Arunthathiyar, and b. Chakkiliyar. As per the 2001 census, the total population of Tamil Nadu is $62,405,679$. Of these, 11,857,504 (19 per cent) people belong to the Scheduled Castes. Of the total Scheduled Castes' population, 771,659 (6.5 per cent) people belong to the Arunthathiyar and 777,139 (6.6 per cent) people belong to the Chakkiliyar castes. According to the census, the Arunthathiyar and the Chakkiliyar castes have 53.7 per cent and 50.9 per cent literacy rate respectively.

\section{Colonial Characterization of the Caste}

What colonial census, gazetteers, manuals, travel accounts, etc., apprised about the Chakkiliyars became a standard characterization of the caste in official records and scholarly writings. It, in fact, has contributed to one-dimensional narrative; the deconstruction of which started only recently. Colonial administrators-scholars generally collected their information through the help of educated, English-speaking upper caste assistants. Details of castes were often collected from village heads, and accountants / scribes like karanam, kanakkapillai, nattamgars, etc. ${ }^{7}$ Prior to the castebased census surveys, the Christian missionaries working in different interior regions had documented their personal accounts of various castes. In the nineteenth-century scenario, any narration about a lower caste was often a result of a combination of

\footnotetext{
${ }^{7}$ For example, Nicholson says, 'the survey began in June 1802 and was made by "karanams and nattamgars, who bound themselves to render true and faithful accounts.' Nicholson, Augustus. (1887). Manual of the Coimbatore District in the Presidency of Madras. Madras: Government Press. (p. 100).
} 
colonial-official, missionary, and upper castes' prejudices/perspectives, in addition to, of course, the possible social and historical reality of the caste.

As per the existing written documents, the name Chakkili first appeared in a thirteenth-century temple inscription ${ }^{8}$ and continued to find its reference in documents throughout the medieval period. Early colonial documents used some variants of the same. Of these, Chuckler ${ }^{9}$ was most prevalent while others being Siclar or Shecliar, ${ }^{10}$ Sakkili, Cakkili, ${ }^{11}$ Shakkili, ${ }^{12}$ Chuckili, Chakkiliyan $/ r,{ }^{13}$ and Sakkiliyan $/ r .{ }^{14}$ In fact, the colonial surveyors were aware about the derivation. For example, in 1871, Cornish (1873, p. 37) made it clear that 'The Chakkili are the well-known chucklers; to use a corruption that has now become an English word.' Richards (1916, p. 201), while explaining about the five castes of Panchamas, writes that this category included 'the chucklers or more correctly sakkiliyans.'

This attempt towards the correct pronunciation of the caste name, from Siclar to Chakkiliyar and Sakkiliyar, correlates with the long process of colonial venture to explore more about the caste. At present, in non-official use, Arunthathiyar and Chakkiliyar are used in a very pluralistic sense. Within these broader categories, there were sub-divisional identities like Pagadaiyar, Madhariyar, Thottiyar, and many more. ${ }^{15}$ Some of them were certainly names of the titles that the community adopted at different points in time and they eventually became names of castes. The Chakkiliyars were, in certain early documents, mistakenly identified with the Paraiyars and sometimes with the Telugu-speaking Madigas, perhaps due to their identical occupations and social condition. ${ }^{16}$ In the seventeenth century, in the Tamil regions under the rule of Carnatic Nawabs, they, along with other similar castes, were included into a common social identity, namely the Panchum Bundum (Buchanan-Hamilton, 1807, p. 19).

Given the enormity of caste divisions in South India, early missionary accounts, colonial surveys, manuals and gazetteers had focused very little on the Chakkiliyars. ${ }^{17}$ Moreover, they tend to freely borrow from each other and reproduce same statements

${ }^{8}$ South Indian Inscriptions, Vol. VIII, No. 151.

${ }^{9}$ For example, Cornish, W. R. (1873). Census of the Town of Madras, 1871. Madras: George Gazette Press. (p. 34).; Fanu, Le. (1883). A Manual of the Salem District in the Presidency of Madras, Vol. 1. Madras: Government Press. (p. 131).

${ }^{10}$ Buchanan-Hamilton, Francis. (1807). A Journey from Madras through the Countries of Mysore, Vol. 1. London: Cadell and W. Davies. (p. 19).

${ }^{11}$ Oppert, Gustav Salomon. (1888). On the Original Inhabitants of Bharatavarsa or India, The Dravidians. New Delhi: Asian Educational Services. (p. 66).

${ }^{12}$ Wilson, H. H. (1855). Glossary of Judicial and Revenue Terms. London: W. H. Allen and Co. (p. 54).

${ }^{13}$ Thurston, Edgar (1909). Caste and Tribe of South India, Vol 2. Madras: Government Press. (p. 4).

${ }^{14}$ Ayyer, S. Krishnamurthi. (1922). Census of India 1921, Volume XXV, Travancore, Part-1. Trivandrum: Government Press. (p. 107).

${ }^{15}$ This category also included adi-andhra and adikarnataka.

${ }^{16}$ McIver, Lewis. (1883). Imperial Census of 1881 Operation and Results in the Presidency of Madras, Vol. III. Madras: Government Press. (p. 128).; Pandian, Thomas B. (1895). Slaves of the Soil in Southern India. Madras: Cosmopolite Press. (p. 23).

${ }^{17}$ Caste based surveys posed great difficulty. For example, Imperial Census of 1881 says, 'in some case the same word with a slight difference in spelling gave the name of a different caste,' McIver, Lewis. (1883). Imperial Census of 1881 Operation and Results in the Presidency of Madras, Vol. III. Madras: Government Press. (p. 129). 
about social ranking, rituals and cultural practices, occupation and food habits, etc. There was, therefore, hardly any fresh investigation about the caste except a few occasional additions here and there. All these early observations were compiled and put together by Edgar Thruston in his Castes and Tribes of Southern India in 1902. Like for many other castes, his account of the caste becomes a starting point for later studies of the Chakkiliyars.

In 1868, Nelson called the Chakkiliyars a caste of exceptionally beautiful, virtuous women. ${ }^{18}$ For this, they are classified into the Padmini category of women. ${ }^{19}$ Baines (1912, p. 79) observed, 'It may be noted that the leather-workers are here, as in north, remarkable for the beauty of their women and in those stage of Sakthi worship at which the presence of a living representative of the female energy, is necessary, a Sakkilian is always selected for the part.' These beautiful women were possibly subjected to sexual exploitation by the landlords: 'Zamindars and other rich men are very fond of intriguing them' (Nelson, 1868, p. 73). But men are 'debased, drunken, and improvident' (Cornish, 1873, p. 37) 'addicted to gluttony and intemperance'; 'fond of eating the flesh of deceased cattle' (Taylor, 1847); 'men of filthy habits and their morals are very bad' (Nelson, 1868, p. 73). Missionaries were less sympathetic while describing the backwardness of the Chakkiliyar men. Dubois (1897, p. 62) observes: 'their orgies take place principally in the evenings, and their villages resound, far into the night, with the yells and quarrels which result from their intoxication.' About women, he says, 'the women of the wretched class do not allow their husbands to outshine them in any voice' (Ibid, p. 62). Pandian (1898, p. 45) observes, 'they eat the dead animals which they receive from the villagers as a part of their wages.' Colonial accounts of the caste also observe, perhaps mistakenly, that the men and the women of the Chakkiliyar caste, as those of the Palli / Pulli caste, belonged to two antagonistic premodern caste divisions, viz. the right-hand and the left-hand castes. ${ }^{20}$ Starting from Nelson's Manual of Madura Country, the possible social practices of the Chakkiliyar women keeping aloof from their husbands whenever riots between these castes' divisions erupted has been recounted. ${ }^{21}$ Such practices indicate, as

${ }^{18}$ Nelson, J. H. (1868). Madura Country: A Manual. Madras: Asylum Press. (p. 73).; Richards, F. J. (1916) Madras District Gazetteers, Salem. (p. 204). It should not be an exaggeration. Such view is quite prevalent among village communities even today. Women of Chakkiliyars are very much sexually exploited.

${ }^{19}$ Ancient Sanskrit erotic texts classify women into several types according to their characters. Of these, Padmini is one. See Rati Rahasya of Pandit Kokkoka (trans. S. C. Upadhyaya, 1965). Bombay: Treasure House of Books. (p. 18).

${ }^{20}$ Nelson, J. H. (1868). Madura Country: A Manual. Madras: Asylum Press. (p. 7).; Murray Aynsley. (1883). Our Tour in South India, (London: F. V. White and Co). (p. 251); Arthur Maurice Hocart. (1968). Caste a Comparative Study. New York: Russell \& Russell. (p. 66),; John Dawson Mayne. (1878). A Treatise on Hindu Law and Usage. Madras: Higginbotham \& Co. (p. 72).; Oppert, Gustav Salomon(1888). On the original inhabitants of Bharatavarsa or India, the Dravidians. New Delhi: Asian Educational Services. (p. 66). For discussion with regard to Palli/Pulli, see; Maclean. (1987). Administrative Manual, Vol. I, (p. 69).; W. R. Cornish (1874), Report on the Census of the Madras Presidency 1871, Vol. 1, (p. 169).

${ }^{21}$ Nelson, J. H. (1868). Madura Country: A Manual. (Madras: Asylum Press). (p. 7).; J. A. Murray Aynsley (1883). Our Tour in South India (London: F. V. White and Co). (p. 251).; Arthur Maurice Hocart (1968), Caste a Comparative Study. New York: Russell \& Russell. (p. 66).; 
Mayne (1878, p. 72) presupposed, there had been cross-marriages between men and women of different tribes.

Like many others, Richards (1916, p. 203) placed them below the Paraiyars and says 'they are accounted the lowest of all in the social scale, even the Pariahs despising them.' Like the Paraiyars, the Chakkiliyars lived in the outskirts of villages, the untouchable habitats (theenda cherri). Richards (1916, p. 107) has used the term sakkili-nattam to refer to the habitat of the Chakkiliyars. Nattams are generally located in the central part of a village - the habitats of upper castes. Some such sakkili-nattams might have existed where the Chakkiliyars had the opportunity to own and cultivate land. Otherwise, their mingling with other castes (upper) in the village was mainly because of occupational and service needs of the dominant communities.

In various gazetteers, the Chakkiliyars were invariably called demon or devil worshippers. Their beloved gods/goddess, such as Madurai Veeran, Ayyanar, Ellaiyamma, Mariyamma, and Muniyan were viewed as demons by the census surveyors. One can plausibly argue that there might have been considerable regional variations in their ritual and religious practices. Responding to the general wave of sanskritization, they might have also attempted to attach themselves with the two South Indian chapters of Hinduism, namely Shaivism and Vaishnavism. In a district like Tanjore, Thurston (1909) mentions that they wore namam, a mark of Vaishnavite following. In Coimbatore district, in the opinion of Baliga (1957, p. 215), 'normally they are Saivite but are in reality devil worshippers.'

\section{From Leather Workers to Municipal Corporation Sweepers}

By occupation, the Chakkiliyars can be grouped as leather workers. There are also evidences that many of the Chakkiliyars were landowners and engaged in cultivation. Many of them in certain places remained landless farm workers that included cattle keepers. Archival records indicate they made leather baskets which were essential for lift irrigation of the time. Leather work involved engaging with dead cattle. It perhaps, in course of time, brought the Chakkiliyars to do the so-called unhealthy jobs, like burying the dead, conducting death rituals; and gradually, during the later period, as sanitation workers and municipal corporation sweepers.

The transition, from perhaps a respectable status of a leather worker to a farm slave (pannaiyal) or to a sanitation worker explains the social trap in which the Chakkiliyars were caught. A thirteenth-century temple inscription gives the first solid evidence to the name - Chakkiliyar. It clearly mentions the procurement of leather materials from them. ${ }^{22}$ The Chakkiliyars' primary engagement with leather might have started much before and continued until modern industrial products replaced the indigenous crafts. Standard colonial definitions of the Chakkiliyar are: 'the leather workers of the Tamil districts', 'a low caste working in hides and leather', 'a currier, a shoemaker', 'their hereditary vocation is the tanning of and working with leather', 'the principal leatherworking caste', 'native cobblers', etc. (Cox, 1894, p. 239; Richards, 1916, p. 203; Baines, 1912, p. 79; Gleig, 1828, p. 245)

John Dawson Mayne. (1878). A Treatise on Hindu Law and Usage. Madras: Higginbotham \& Co. (p. 72).

${ }^{22}$ South Indian Inscriptions, Vol. VIII, No. 151 
The respect for leather work and the demand for leather products determined the social status of the Chakkiliyars. In various village festivals and folk rituals, the thol (leather) occupies a significant position, indicating the importance of leather craft and craftsmen. The ritual practice of offering leather shoes to local deities continues even in present times. In 1820, Walter Hamilton (1820, p. 472) observed:

At Madura there is famous temple in a place called Pahlary, consecrated to God Vellayuda, to whom his devotees bring offerings of a singular kind. These consist of large leather shoes of the shape of shoes which the Hindus wear on their feet, but much larger and ornamented. The deity of the place being much addicted to hunting, the shoes are intended to preserve his feet when he traverses the jungles.

In addition to shoe making, the growing agrarian expansion in frontier regions, especially where farming primarily depended on well irrigation, provided new economic opportunity. The Chakkiliyars produced durable, weightless leather bags which were used for lifting water. In Coimbatore district manual, Nicholson (1887, p. 251) describes about the use and value of leather bags and sandals:

Leather well-buckets are a source of much profit to the chucklers; each welllift requires a new one every year, and as there are 83,622 lifts in actual use, about 80000 buckets, each requiring one ox hide, are used per year. These are probably the leather cases (bags) of the census. They are circular-mouthed bags, about two feet wide, tampering for about three feet, and fastened to a leather tube some four or five feet long. Their cost is about Rs. 6. Raw buffalo hide ropes are frequently used for those lifts. Leather sandals are also made in vast quantities by the chucklers and are sold at 8 to 12 annas, per year.

This integration of their craft with the agrarian economy would have earned them considerable social respect. In 1921, there was substantial increase in the population of the caste in Travancore (104 per cent increase compared to 1911). 'The demand for their labour,' writes S. Krishnamurthi Ayyer (1922, p. 107), 'caused by the increase in the number of persons using leather goods might have induced other castes to take up their profession and return themselves as Sakkiliyan.' But it did not last long. These leather workers were gradually integrated into farm work. Many, along with their families, were attached to a big landlord who provided food and occasional gifts for their service. Men, women, and children were assigned different tasks - sweeping, herding, and farming. Their task of cleaning in rural places included managing burials of dead humans and animals, and various services and rituals associated with it. This practice, continued till recently, represented the emergence of agrestic slavery in western Tamil Nadu.

Despite all social restrictions, there are clear evidences that in certain pockets, the Chakkiliyars themselves cultivated lands or at least remained as tenant cultivators. Not only in the western fringes, even in the interior riverine basins of Tamil Nadu, it is quite possible; one comes across names of places such as chakkili thottam (wetland of the Chakkiliyars), ${ }^{23}$ chakkiliyan kadu (dryland of the Chakkiliyars), ${ }^{24}$ chakkilipalayam

${ }^{23} \mathrm{~A}$ place in Marurpatty of Namakkal district.

${ }^{24} \mathrm{~A}$ place in Chettipalayam of Coimbatore district. 
(village of Chakkili), ${ }^{25}$ chakkiliyan vaikkal (the Chakkiliyar canal), ${ }^{26}$ chakkilichimadai (channel of Chakkili women), ${ }^{27}$ etc. In Pudukkottai state, writes Ayyer (1933), 'the highest number of Chakkiliyans are in the Viralimalai division apparently for the reason that there is a good deal of well irrigation in that division. There had been land transfers from the community to other upper castes. ${ }^{28}$ Even today a few members of the caste own land and still cultivate. But somehow the Chakkiliyars were not able to sustain success in cultivation. The acquired landownership neither led to their progress economically nor did it bring them any social respect.'

Exploring how the Chakkiliyars acquired land makes us look at their role in medieval states. A major source of acquiring landownership during the medieval period was participation in the military. Often dynastic changes resulted in the creation of a new class of landowners, who initially helped them in military invasions. The rule of the Nayakas and later the Carnatic Nawabs in Tamil Nadu during the sixteenth and eighteenth centuries helped the entry of Chakkiliyar men into their troops and the consequent benefit of landownership. On April 30, 1800, when Buchanan (1865, p. 19) stopped his journey at Vellore to give rest to his men, he observed:

The greater part of the Brahmans in the lower Carnatic follow secular professions ... much of the land is rented by them; but, like the Jews, they seldom put their hand to actual labour and on no account will they hold the plough. Their farms they chiefly cultivate by slaves of the inferior castes, called Sudra and Panchum Bundum.

The Panchum Bundums are by far the most hardy and laborious people of the country, but the greater part of them are slaves. So sensible of their value was Hyder, that in his incursions it was these chiefly, whom he endeavoured to carry away. He settled them in many districts as farmers and would not suffer them to be called by their proper name, which is considered opprobrious; but ordered that they should be called cultivators. The Panchum Bundum consists of four tribes: the Pariar, the Baluvan, the Shecliar, and the Totti. The Shecliars dress hides, and from among the Totti is chosen a particular class of village officers. ${ }^{29}$

Two other occupations in which the Chakkiliyars possibly engaged are the village guard and various services in the temple and the military. Evidence suggests, in some places, that the Chakkiliyars guarded the villages, cultivated crops, worked in water reservoirs, and looked after cattle. Early medieval inscriptions confirm their engagement with the temple, especially to make musical instruments which required leather. These kinds of traditional practices continued till recent times. For example, in the Manual of the Pudukkottai District, K. R. Venkataramayar (1930, p. 336) wrote: 'in a village where originally four chucklers (leather workers) provided hides for the temple drum at one hide each, four hides continued to be exacted over though there was only one chuckler surviving.' Similarly, if not as soldiers, their service was also essential for producing and repairing leather products used by the troops. The Nayakas

\footnotetext{
${ }^{25}$ A place mentioned in Sources of the History of the Nawabs of the Carnatic. Madras: University of Madras 1934. (p. 111).

${ }^{26}$ A place in Thalanayaru, Nagapattinam district.

${ }^{27}$ Mentioned in The Law Weekly, Vol. 6, 1917 (p. 582)

${ }^{28}$ Learned from a field work in Sathayamangalam of Coimbatore district

${ }^{29}$ For further references see James Kerr. (1865). Domestic Life, Character and Customs of the Natives of India. London: W. H. Allen \& Co. (p. 276).
} 
and the Carnatic Nawabs employed craftsmen from this community in considerable numbers (Margu, 2001). Such military opportunities increased with the establishment of European rule from the eighteenth century. A western military dictionary defines 'chuckler' as: 'an Indian term, signifying a cobbler, or worker in leather.' This class of men is employed in all government establishments in India where leather work is made up (Farrow, 1885, p. 354). One of the correspondences of Field Marshal Arthur Duke of Wellington (1820, p. 276), dated 1804, reads: 'it, in general, also authorizes you to entertain two chucklers, for keeping the leather boats in repair, and a conicopoly, at ten pagodas per month, for paying the men and keeping the account ...'

Moreover, there are still people in the community who continue to believe in a glorious and ruling class ancestry. We do not have much written evidence to support this view. In Genji of Vizhupuram district there were a series of forts, collectively known as Genji Fort. Dating back to the eleventh century, these forts, constructed at different points, came under several successive rulers of this region. It included, the Cholas, Vijayanagar rulers, Bijapur Sultans, Carnatic Nawabs, and later, the Europeans. One of the hill forts in this group is known as Chakkili Durg (Chakkili Durgam/Kottai/Malai) (Varadarakam, 1985, p. 1319). It is believed, 'a sardar of the shoe-maker caste fortified (the hill) at his own expense' (Srinivasachari, 1943, p. 88). In Genji region there is a prevalent popular memory of one 'Chakkili Maharaja' (the great Chakkili King) (Umamaheswari, 2018, p. 117). There is also a reference to a Chakkili zamindar (landlord and chief) in Thirunelveli region. In 1895, Pandian (1898, p. 23) in his Slave of the Soil in Southern India, records a memory, 'the writer was once informed by the present zamindar of Avidayapuram, in the district of Tirunelvelly, that this zamindari was once under a Chackla king.' But all these opportunities benefitted a minuscule portion of the community without hardly any economic and social mobility to the caste as whole. Changes in the occupation did not erase the stereotypes attributed to the caste.

While the agrarian economy made the Chakkiliyars farm labourers and agrestic slaves, the urban-based industrial economy made them sanitation workers. By 1871, a sizable number of Chakkiliyars settled in the outskirts of emerging urban areas and engaged in new occupations. The Census of Madras Town of that year says: 'The Chakkili caste will work in degradation and shame, that they will perform the most distasteful of works, and the greater portion of the members of the caste are now scavengers, both public and private.' The municipal sweepers are generally Chakkili (Cornish, 1873, p. 37). The 1911 census report of India gives various occupations in which the Chakkiliyar were engaged in the Madras Presidency: 'leather workers -222.6/1000, owners / tenants - 17.6/1000, field labourers - 468.1 / 1000, labourers 258.5/1000, and others - 33.2/1000' (Molony, 1912, p. 245).

\section{Chakkiliyar Leather vs. Godown Leather}

With the emergence of modern industries, leather craftsmanship got mechanized. Similarly, leather products like water bags, which were essential for well irrigation, lost their value. Motor pumpsets replaced the traditional water-lifting technology called kabalai. Other industrial products in metal/plastic gradually replaced leather products. Some Western entrepreneurs set up leather industries that employed the Chakkiliyars in production activity, thus making some of them part of the industrial working class. However, the community altogether lost its livelihood considerably. The craftsmanship of the Chakkiliyars was considered primitive, causing extensive wastage of leather. Even before the advent of modern leather industries, the Labbais, 
Muslim leather workers, gave a tough competition to them. In certain regions leather work passed into the hands of Labbais. 'Leather tanning is chiefly in the hands of the Labbais of the Arcot and Gudiyattam Taluks. Chucklers in various parts of the districts prepare leather, in a rough way, with chuman and barks, but the best is made by the Labbais,' wrote Stuart (1894, p. 171). Richards (1916, p. 272) observed:

Village-tanned hides are the crudest. The work is usually done by chucklers and the leather is known in the market as 'chucklers' leather. It is only in Salem Town that their finished hides are known as 'godown leather'. It is only in Salem Town that finished hides are produced. They are known legally as patnan-itta-tol.

By the beginning of the twentieth century, the leather-working Chakkiliyars gradually lost their livelihood and those who survived in this profession, found their activities reduced to just shoe-repairing rather than manufacturing. There were also changes in their rights to village hides. As the value of leather products was fixed based on the demand in the global market, the traditional practices were gradually abandoned. Further, the steady increase in the value of hides compelled some village leather workers to sell the hide directly without tanning. This again disturbed the traditional pattern of leather work. For example, a colonial report states:

The increased value of the hides and the ease with which they can be marketed have led the chuckler in many places, to abandon the tanning business and to sell the hides to dealers for cash. It has also led the villagers to dispute the chuckler's right to the hides, and to employ him instead as an intermediary in the disposal of their hides while he now purchases leather in the open market from the agents or middlemen of the organized tanneries and send it over to a chuckler or make up into whatever he needs ...,30

The establishment of private leather industries finally minimized the use of the 'Chakkiliyar leather'. On seeing the growing commercial value of hides in the international market, the Madras government put in efforts to improve the tanning methods. 'The first step towards improving matters was taken by the Madras government when they sanctioned in 1903 the experiments in chrome tanning, which, eventually led to the establishment of the Government Chrome Tannery at Sembiem' (Molony, 1912, p. 211). In 1910, two private chrome tanneries were established and the government factory was sold.

A 1915 report on leather manufacturing in Madras Presidency gives data reflecting the contemporary trends:

The total value of leather tanned in the Presidency being in normal times about Rs. 31/2 crores annually. In 1901 the number of persons engaged in the manufacture of leather was 9268. By 1911 it had increased to 13734. But in the same period the number of persons engaged in the manufacture of leather articles decreased from 50795 to 37028 . This fall was partially due to the rise in the value of leather, which led to it being replaced by iron as the material ... is leading to the gradual extinction of the village chuckler and a corresponding increase in the efficiency of production ... ${ }^{31}$

\footnotetext{
${ }^{30}$ The Journal of the American Leather Chemist Association, Vol. 14, 1919.

${ }^{31}$ A Madras State Administration Report, 1915. Madras: State Press. (p. 73). Also see, Indian Industrial Commission Report, 1916-18. Calcutta: Government Printing, 1919. (p. 53).
} 


\section{Education: The Missionary Efforts}

Compared to other lower castes, the Chakkiliyars responded sluggishly to the missionaries' attempt to educate them and uplift the lower castes. Cornish (1873, p. 37) wrote: 'Education has no charm for them, and they never responded to the attempts of the missionaries to gather them in schools.' Similarly, very few converts worked as native agents, school masters, catechists in the missionary-supported institutions. In 1871, in the educational ranking, the Chakkiliyar caste comes last to the position of 63. The Thottiyars and the Paraiyars occupy better ranks of 62 and 45 respectively (Ibid, p. 35). The relatively better position of the Paraiyars was possibly due 'to their frequent employment in European domestic service' (Molony, 1912, p. 125). The census report of 1911 gives a rough estimation of literacy among the Chakkiliyars. According to the report, among 261,421 Chakkiliyar men, 2,449 were educated. Similarly, out of 265,030 women, only 194 were literate (Ibid, p. 80).

Cornish (1873, p. 37) compared the thirst for education between a community called the Panisevan and the Chakkiliyar, thus:

It is interesting to contrast the different results of educational effort among the Panisevan and Chakkili. The former are nearly the highest, the latter all but the lowest in the list, and yet both are poor, the Panisevan more so. Both are looked down upon, although the Chakkili are very far below the Panisevan.

\section{A Caste Test: Chakkiliyars in Church}

Missions often underwent what they called a 'caste test' with an objective to suppress the caste distinction among the converts/pupils employed or enrolled in mission institutions. The caste test was typically meant to inspect whether the converted employees or students in mission boarding schools were able to intermingle with each other irrespective of their caste identity and status. More specifically, whether they were able to share the eating area, to sit and eat together, or to accept the food cooked by a lower caste person. This is an issue which is prevalent even today among the castes in Hindu/Christian society. If a person accepts and drinks a glass of water offered by a person from a lower caste it indicates his/her acceptance of the person vis-à-vis caste. The head of a local mission puts it aptly: 'If a Shanar would eat with a Pallar, or both with a Pariah or Chucklear, I should consider that the person so doing would give sufficient proof of his renunciation of caste, at least as far as eating is concerned.' ${ }^{32}$ Or another ideal parameter of absence of caste distinction should be 'a Vellalan girl and a Chuckler, the highest and lowest, walking hand-in-hand as friends in a boarding school' (Ibid, p. 100).

Heads of missions used to periodically subject the local missions to this caste test. They sent questions in this regard and received varied replies. Some of the local heads' observation read like:

'It is a most saddening fact to notice the total absence of caste distinctions in our School (as to see a Vellalan girl and a Chuckler, the highest and lowest walking hand in hand as friends) followed by the entire distinction, in reference

\footnotetext{
${ }^{32}$ Reports on Inquiries Made by the Bishop of Madras, Regarding the Removal of Caste Prejudice and Practices in the Native Church of South India. (1868). Madras: The Christian Knowledge Society Press. (p. 8)
} 
to marriage, as soon as they get home. It is of course owing to the influence, the conversation, the bringing up, of their parents and relatives' (Ibid, p. 100).

'It must not be forgotten that low caste people have as much caste as the high castes, if not more. Even a chuckler who is looked upon as belonging to the lowest caste will not eat with certain castes. It is easier to persuade a high caste man to give up caste than a low caste man. When the former abandons caste he does it to a greater extent than the latter' (Ibid, p. 114).

'One of the communicants under me, a man of good caste and one who is well to do in the world and who has many rich heathen relatives about him, has been freely and voluntarily eating with his chuckler brethren who are considered to be the lowest and most dreaded caste here: and this was done not in private but in a place where it might be noticed by hundreds of people' (Ibid, p. 126).

'In the village of Tyalapolu I have a Chuckler convert; and every one of my agents has either taken food with him in their own houses, or they have gone to his house in the course of duty, and there they have eaten rice prepared by his wife and drank water from his vessels' (Ibid, p. 144).

These observations, no doubt, indicate the efforts of certain missionaries to abolish caste inequalities and to bring lower castes like Chakkiliyar, Paraiyar, Pallar, and Shanar into the Church and its educational institutions. But when compared to other lower castes, the proportion of the Chakkiliyars in Church was very negligible.

\section{Claims of the Communities: The Paraiyar and the Chakkiliyar}

The antagonism between the Paraiyars and the Chakkiliyars is well-known and longstanding. Various documents from the eighteenth century refer to the confrontational relationship between these castes. Having been federated themselves in two opposite factions of castes (the right hand and the left hand), these castes claimed different cultural and social rights. One of the visible distinctions between these factions is, writes Richards (1916, p. 125), 'that at festivals and marriages the right hand castes employ Pariah musicians with pipes and horns, while the left-hand castes employ only Chackler musicians with drums and tom-toms of various kinds.' Nonetheless, Oppert (1888, p. 66) observes, 'the Pariahs and the Cakkilis, when not actually engaged in hostilities, acknowledged each other in a friendly manner as brother-in-law.' In fact, in the early census surveys (of 1871, 1881, and 1891), the Chakkiliyars were put in a broader category of Pariah. In 1871, Cornish (1874, p. 170) wrote, 'There are numerous sub divisions of the Pariahs, but the more common are the Paraiah, the Pallan, the Chuckler and Toti.' In the list of Tamil sub-castes given in the census of Madras Presidency (1881), there are nearly 27 castes with the suffixed title of 'Sakkili'. It is important that these castes are not found in the list of Telugu and Kanarese sub-castes, though a few appear in the Malayalam list. ${ }^{33}$ There are some more sub-castes with the title mentioned in later reports and other contemporary reports. These include 'Amma Chakkili, Thotti Chakkili, Murasu Chakkii' (Census of India, 1961), 'Arava Chakkili,' (Singh, 2006, p. 125) 'Reddi Sakkili, Vaduga Sakkili' (Cornish, 1874, p. 130). Some of these sub-castes are common to both the Chakkiliyar and the Paraiyar which indicate that certain sections of these castes, if not the whole,

${ }^{33}$ However, some census reports put them in the Telugu castes' list. 
had a common origin. In one of the articles that appeared in the Madras Mail and the Madras Times, the author, whose name is given as 'Native' puts these communities into a category of 'conquered people' and says:

'Both the Pariah and Chuckler people and a whole lot of other half-wild tribes with whose names we will not trouble the reader, are supposed to be the aborigines of the country, and there is a good deal in much of their peculiar customs as linger with them at the present day that justifies such a supposition. The very fact, for instance, of their being reduced to their present state of degradation is in itself proof that they must have been a conquered people, that several successive waves of foreign invasion must have passed over their heads, they become the deposed and wretched people they are now. (Richards, 1916; p. 125)

Dubois notes the significant contribution of the Paraiyars and the Chakkiliyars in economic activities. These communities represented at least a quarter of the contemporary population. In addition to various hard and indispensable odd tasks, the agrarian activities of the country mainly depended on their labour. Dubois (1897, p. 51) writes, 'it is painful to think that its members, though so degraded, are yet the most useful of all.' In the Hindu caste hierarchy, as discussed in later sections, the Chakkiliyar comes after the Paraiyar and there is rarely any caste below the Chakkiliyar (Karasimha, 1997). It is probably due to the Brahmanization wave which began in Tamil Nadu during the early medieval period and contributed to the consolidation of a caste-based social structure thereafter. The cow is a holy animal and venerated by the upper caste Hindus. In the eighteenth-century context, Pierre Sonnerat, during his voyage to the East Indies, observes: 'the Chakkiliyars are in more contempt than the Pariars because they use cow leather in making shoes' (Thurston, 1909, p. 6).

It is interesting that these communities which were expected to come together since both belonged to an exploited class and were ill-treated by the upper castes, instead fought with each other. The fight between the left and the right might have started among the middle castes which took up new occupation and claimed various social and cultural rights. But this feud in later periods survived among the lower castes such as the Paraiyars and the Chakkiliyars. As observed by many, the discontent was intense. Dubois (1897, p. 27) provides one of the earliest accounts of the continuation of the fight during the eighteenth century, where he observed one such animosity:

I once witnessed a dispute of this nature between the Pariahs and Chucklers or leather workers. There seemed reason to fear such disastrous consequences throughout the whole district in question that many of the more peaceful inhabitants began to desert their villages and to carry away their goods and chatterls to a place of safety, just as is done when the country is threatened by the near approach of a Mahratta army. However, matters did not reach this extremity. The principal inhabitants of the district opportunely offered to arbitrate in the matter, and they succeeded by diplomacy and conciliation in smoothening away the difficulties and in appeasing the two factions who were only awaiting the signal to attack each other. One would not easily guess the cause of this formidable commotion. It simply arose from the fact that a Chuckler had dared to appear at a public ceremony with red flowers struck in his turban, a privilege which the Pariahs alleged belonged exclusively to the right-hand faction. 
Such reports about fierce rivalry between these two castes are numerous. Richards (1916) observed that the larger feud between these right-hand and left-hand castes primarily emerged from the rivalry between the Paraiyars and the Chakkiliyars. He wrote: 'The factious feeling that subsists between the right-hand and left-hand castes is concentrated in the primeval feud between pariahs and chucklers, and the brawls that still occasionally give vent to this feeling are generally precipitated by a collision between these two castes' (1916, p. 203). These castes will not accept food or water from each other. An observation in a report on the Madras native army goes like this: 'Pariahs are not really in the caste scale at all still they will not eat with, or take water from the hands of a Chuckler or Pallar.' ${ }^{34}$

One can easily presume that the root cause of the social tension lay more in the shrinking economic opportunities of the communities. It is believed the Chakkiliyars later migrated and their settlement in villages curtailed the existing employment opportunities of the Paraiyars. Emphasizing this, Baines (1912, p. 79) writes, 'it is probably therefore, an offshoot of Madiga, moved south, imparting it with its traditional rivalry with the village serf, for there is constant bickering between the Sakiliyan and the Paraiyan ...' Yet, viewing this rivalry as a fight between the early inhabitants and migrants is problematic. In social vertical classification, the Chakkiliyars often come immediately after the Pariahs. Cornish (1874, p. 169) included them, along with the Paraiyars, into a category which he called 'slaves of the superior castes'.

\section{Migration and Linguistic Identity: The Chakkiliyars and the Madigas}

Colonial ethnographers' understanding stems mainly from the caste accounts of early census reports. The reports of Madras Presidency, which included substantial parts of the Kanarese- and Telugu-speaking regions, evidently confused various leatherworking castes with one another. Early reports identified the Chakkiliyars with the Telugu-speaking Madigas, and both together were classified under the broader caste division of the Pariahs. District manuals and gazetteers expressed the same trend, while partially clearing the confusion. For example, Nicholson $(1887$, p. 63) while writing about the census report of 1881 makes this observation: 'In the census report Madigas, i.e. Chucklers (Sakkiliyar) have been included amongst Pariahs: this is certainly incorrect, as the two classes are wholly distinct.' While the Pariahs were considered distinct from the Chakkiliyars, the Madigas were identified as Chakkiliyars. There were three perspectives prevalent during this time: 1. The Chakkiliyars and the Madigas are one and the same; 2. The Chakkiliyars are one subdivision of the Madigas; and 3. Tamil- and Telugu-speaking leather workers are Chakkiliyars and Madigas respectively.

In some reports, the Madigas were called Telugu Chakkiliyars, and similarly the Chakkiliyars as Tamil Madigas. It is only in the later reports that a broader understanding of classifying the Madiga leather workers in the Telugu-/Kannadaspeaking regions, and the Chakkiliyars as leather workers of Tamil-speaking regions was developed. For example, Nicholson $(1887$, p. 63) corrects his own mistake by stating, 'the Madigas or leather-workers of the Telugu Kanarese country, according to the census reports are confined to Hosur Taluk, but as already stated, it is not unlikely that many of them have been included among the Chucklers.' To clear the confusion,

${ }^{34}$ The Madras Native Army, The Calcutta Review, Vol. XXXIII, July-December, 1859 (p. 142). 
Salem district gazetteers gave a list of lower castes in Panchama category. It included six castes: 1. The Tamil Pariahs or more correctly, the Paraiyars; 2. The Telugu Malas; 3. The Kanarese Holeyas; 4. The Valluvans or Pariah priests; 5. The Chucklers or more correctly the Sakkiliyans; and 6. The Madigas, both Telugu and Kanarese (Richards, 1916, p. 201). Tamil stone inscriptions, from the thirteenth century onwards, give reference to this caste. ${ }^{35}$

At present, the linguistic identity of the Chakkiliyar is crucial to their claim of indigenous Tamil origin. While other powerful lower castes, such as the Paraiyar and the Pallar, speak only Tamil and could easily trace their origin to inscriptions and early Tamil literatures, it remains difficult for the Chakkiliyars. Genetic studies indicate their morphological closeness with the Paraiyars and the middle castes, like Kallars (Vijaya, Kanthimathi \& Ramesh, 2008). Similarly, the popular cult practice of the Madigas, the worship of the Matangi, is not followed by the Chakkiliyars (Thurston, 1909). They do not have the practice of offering their daughters. Therefore, except sharing the same occupation, the Chakkiliyars seem to have no significant connection with their counterparts, the Madigas.

Yet, some members of the Chakkiliyar caste speak Telugu also and gazetteers have mentioned it (Richards, 1916, p. 201). The members of the community today reflect a circular migration. Since most of the Chakkiliyars live in the border regions, many used to migrate to other regions for work and after considerable duration of stay they would return to their place of origin. This is cited as the reason why some Chakkiliyars speak Telugu or Kanarese. Yet, in all probability, the Chakkiliyars today, as is the case with most other castes, are a mixed group, which include migrants and the 'indigenous' group or the early migrants who engaged in the trade of leather work since the period of classical Tamil literatures. ${ }^{36}$

\section{Documenting the Caste and Social Repercussions}

The colonial and missionary ethnographic accounts show their excitement to gain knowledge about the lower castes and document the complex relationship that existed within them. Though it needs to be scrutinized for their biases and ignorance, they together provide a rich documental evidence to write the social history of lower castes during the early modern period. With regard to the Chakkiliyars, these documents help in addressing certain contemporary political questions, such as their identity and social status and position within the lower castes. But at the same time, these accounts of the caste point out some serious economic and social repercussions. These descriptions often not only recapitulated the stereotypical notions of the Hindus about the Chakkiliyars, but also strengthened it by officially classifying them as 'men working with leather', which directly denoted their engagement with dead cow and eating its flesh. Colonial and missionary representations of the caste rarely captured the world views or outlook of its people; it merely provided an outsider observation. In doing so, it freely borrowed the language of the upper castes. For example, use of sayings such as, 'even a Chakkili girl and the ears of the millet are beautiful when mature' (Thurston, 1909, p. 3) or 'it is said that a Pariah may not bathe in his own well, and

\footnotetext{
${ }^{35}$ South Indian Inscriptions, Vol. VIII, No. 151.

${ }^{36}$ Today the broader category of Chakkiliyar or Aruthathiyar includes subdivisions such as Adi Andhra and the Adi Kannada.
} 
that if he did, the Chuklers would not make or mend his leather buckets' (Nicholson, 1887 , p. 63$)^{37}$ indicate how colonial documents readily implied and propagated the attitude of the upper caste Hindus. Though the colonial administration was in no manner responsible for the deplorable conditions of the Chakkiliyars in Hindu society, yet it accepted the existing caste hierarchy as it was. Further, the appointment of the Chakkiliyars as municipal sweepers worsened their social status and reduced them to a modern category of sanitation workers. The growth of machine-based leather production further diminished their employment opportunities. If the Chakkiliyars trace the history of their ancestry in the colonial and missionary records, they will find that they have a very minute historical significance.

\section{Conclusion: The Social Traps}

Economists use the phrase 'poverty traps' to explain how certain families that once fell into poverty, were rarely, even after generations, able to come out of it (Bannerjee \& Duflo, 2011). To a lower caste in the Hindu society, it is basically the 'social trap' that curtailed their social and economic mobility. The social biases and consequent social and cultural constructions about a caste gradually tightened the grip of this trap. In the case of the Chakkiliyars, such a social trap was stronger than that of other lower castes of South India despite having various opportunities for economic mobility - for example, to utilize the global demand for leather, participate and assist the rulers in military conquests, to own and cultivate land. The social construction of characterizing the Chakkiliyar as one who eats flesh of dead cattle, the holy animal of the Hindus, and associated stereotypes seriously narrowed their path to mobility. The colonial surveys and ethnographic characterization of the caste rarely reflected the reason for their degraded social condition; they rather stated or echoed the Hindu upper castes' notion of the caste. In fact, employing them in low-profile jobs as sanitation workers or municipal sweepers further strengthened the social trap. Until a sub-reservation policy was enacted by the Tamil Nadu government recently, only a few people and families from this caste - most of who were beneficiaries of conversion and missionary education - could break that social trap.

\section{Acknowledgements}

I am grateful to Karventha Magaaraj, Dr. R. Srinivasa Raghavan, Dr. C. Jayaveeradevan and Dr. S. Karmegam for helping me to clarify certain issues that appear in this essay. I also thank the two anonymous reviewers for their comments and suggestions. However, I am solely responsible for all errors.

\section{References}

Arunan. (2010). Kolaik kalankalin vakkumulam. Madurai: Vasantham Veliettakam.

Ayyer, S. Krishnamurthi. (1922). Census of India 1921, volume XXV, Travancore, Part-1. Trivandrum: Government Press.

${ }^{37}$ This folk saying is often used to indicate the confrontational relationship between Paraiyar and Chakkiliyar. 
Ayyer, S. Dandapani. (1933). Census of India, 1931, Pudukkottai state. Pudukkottai: Sri Brihadambas Press.

Baines, Athelstance. (1912). Ethnography: caste and tribes. Strassburg: Karl J. Trubner.

Baliga, B. S. (1957). Madras district gazetteers: Thoothukudi district. Madras: Government Press.

Banerjee, Abhijit, \& Duflo, Esther. (2011). Poor economics: rethinking poverty and the ways to end it. United States: Public Affairs.

Blackburn, Stuart H. (1978). The folk hero and class interest in Tamil heroic ballads. Asian Folklore Studies, 37(1), 131-149.

Buchanan-Hamilton, Francis. (1807). A journey from Madras through the countries of Mysore, vol. 1. London: Cadell and W. Davies.

Cederlof, Gunnel. (1997). Bonds lost: subordination, conflict and mobilization in rural south India c.1900-1970. Delhi: Manohar Publication.

Census of India (1965). Census of India, 1961, Madras, India: Office of Registrar General.

Census of India (2001). Census of India. Retrieved from https://censusindia.gov.in/tables_published/scst/dh_sc_tamilnadu.pdf

Cornish, W. R. (1873). Census of the town of Madras, 1871. Madras: George Gazette Press.

Cornish, W. R. (1874). Report on the census of the Madras Presidency 1871, vol. 1. Madras: The Government Gazette Press.

Cox, Arthur F. (1894). Madras district manuals: North Arcot, vol. 1. Madras: Government Press.

De Heering, Alexandra (2018). Speak, memory: oral histories of Kodaikanal dalits. Pondicherry: Sri Aurobindo Ashram Press.

De Heering, Alexandra. (2016). Dalits and memories: remembrance of days of Past. Economic and Political Weekly, 51(11), 70-77.

Dubois, Abbe J. A. (1897). Hindu manners, customs and ceremonies (trans. Henry K. Beauchamp). Oxford: Clarendon Press.

Farrow, Edward. S. (1885). Farrow's military encyclopedia: a dictionary of military knowledge, vol. I. New York: The Author.

Gleig, George. (1828). The subaltern's log book: including anecdotes of well-known military characters, vol. 1. London: James Ridgway.

Hamilton, Walter. (1820). A geographical, statistical and historical description of Hindostan and the adjacent countries. London: John Murray.

Kaali, Sundar. (2020). Divinity, denial and the embodied self-changing perspectives on untouchability and the case of the hagiographies of dalit Bhatas. In S. Anandhi and Others (Eds.), Rethinking Social Justice. New Delhi: Orient Blackswan.

Karashima, Noboru. (1997). The untouchable in Tamil inscription and other historical sources. In H. Kotanki (Ed.), Caste system, untouchability and the depressed, 21-30. Delhi: Manohar Publication.

Margu. (2001). Arunthathiyar vazhum varalaru. Palayamkottai: St Saviour College.

Marxiagandhi, Na. (1998). Thamizhakathil athiyar marabu. Chennai: Amuthan Publications.

Mayne, John Dawson. (1878). A treatise on hindu law and usage. Madras: Higginbotham \& Co.

Moffatt, Michael. (1979). An untouchable community in south India: structure and consensus. Princeton: Princeton University Press.

Molony, J. Chartres. (1912). Census of India, 1911, Madras, vol. XII, part 1. Madras: Government Press.

Nelson, J. H. (1868). Madura country: a manual. Madras: Asylum Press.

Nicholson, Augustus. (1887). Manual of the Coimbatore district in the presidency of Madras. Madras: Government Press. 
Oppert, Gustav Salomon. (1888). On the original inhabitants of Bharatavarsa or India, the Dravidians. New Delhi: Asian Educational Services.

Pandian, T. B. (1898). Indian village folk: their works and ways. London: Stock.

Pandian, M. S. S. (2000). Dalit assertion in Tamil Nadu: an exploratory note. Journal of Indian School of Political Economy, vol.12(2-4), 1-17.

Richards, F. J. (1916). Madras district gazetteers, Salem, vol. 1, part 1. Madras: Government Press.

Singh, Nagendra Kumar. (Ed.) (2006). Global encyclopedia of the south Indian dalit ethnography. Delhi: Global Publishing House.

Srinivasachari, Chidambaram S. (1943). A history of Gingee and its rulers. Annamalai Nagar: Annamalai University.

Srinivasan, S. \& Ponraj, V. (Eds.) (2010). Dalit kathai padalkal. Chennai: Kavya Publication.

Stuart, Harold A. (1894). Madras district manuals, North Arcot, vol. 2. Madras: Government Press.

Taylor, William. (1847). A memoir of the first centenary of the earliest protestant mission. Madras: Asylum Press.

Thurston, Edgar. (1909). Caste and tribe of south India, vol 2. Madras: Government Press.

Umamaheshwari, R. (2018). Reading history with the Tamil Jainas: a study on identity. New Delhi: The Springer.

Vanamamalai, N. (1971). Muthuppattan kathai. Madurai: Madurai Kamarajar University.

Varadarajan, L. (1985). Memoirs of Francois Martin (1670-1694). Delhi: Manohar Publication.

Venkataramayar, K. R. (Ed.) (1930). Manual of the Pudukkottai state, vol. 1. Pudukkottai: Sri Brihadamba Press.

Vijaya, M., Kanthimathi, S., \& Ramesh, A. (2008). Genetic study of scheduled caste populations of Tamil Nadu. Indian Academy of Science, 87(2), 171-174.

Wellesley, Arthur Richard. (1820). Supplementary despatches, correspondence and memoranda of Field Marshal Arthur Duke of Wellington, 1794-1812, vol. 3. London: John Murray. 